\title{
Corrosion Protection Study of Carbon Steel and 316 Stainless Steel Alloys Coated by Nanoparticles
}

\author{
Rasha A. Jassim* \\ Abdulkareem M. Ali** \\ Received 2, June , 2013 \\ Accepted 8, September, 2013
}

Ahlam M. Farhan*

\begin{abstract}
:
The Corrosion protection effectiveness of Alimina $\left(\mathrm{Al}_{2} \mathrm{O}_{3}, 50 \mathrm{~nm}\right)$ and Zinc oxide $(\mathrm{ZnO}, 30 \mathrm{~nm})$ nanoparticales were studied on carbon steel and 316 stainless steel alloys in saline water $(3.5 \% \mathrm{NaCl})$ at four temperatures: $\left(20,30,40,50{ }^{\circ} \mathrm{C}\right)$ using three electrodes potentiostat.

An average corrosion protection efficiencies of $65 \%$ and $80 \%$ was achieved using $\mathrm{Al}_{2} \mathrm{O}_{3}$ NP's on carbon steel and stainless steel samples respectively, and it seems that no effect of rising temperature on the performances of the coated layers. While $\mathrm{ZnO}$ NP'S showed protection efficiency around $65 \%$ for the two alloys and little effected by temperature rising on the performanes of the coated layers. The morphology of the coated spesiemses was examined by Atomic force microscope.
\end{abstract}

\section{Key words: corrosion protection, Nanoparticles, AFM.}

\section{Introduction:}

Corrosion is an electrochemical phenomenon and is accompanied by the flow of electrical current and its degradation of materials and structures is one of the important issues that lead to depreciation of investment goods [1]. The damages by corrosion generate not only high costs for inspection, repairing and replacement, but in addition these constitute a public risk [2].

To prevent the damage of the systems due to the degradation, a lot of inspections are conducted for the system. In the case of the system periodically suspended, some inspection techniques associated with the thickness measurement such as ultrasonic, laser or other techniques have been employed as powerful tools for diagnosis of corrosion damages [3].

In another words, one can minimize the rate and quantum of corrosion only by providing a suitable environment in which current cannot flow at interfaces. The best corrosion protection is to build a barrier separating the metal from its environment.

Protective coatings are the most widely used corrosion control technique. Essentially, protective coatings are means for separating the surfaces that are susceptible to corrosion from the factors in the environment which cause corrosion to occur. Electroplating, electroless plating, hot dipping, physical vapor deposition, chemical vapor deposition, thermal spraying, electrophoretic deposition, and sol gel are few techniques used for applying coatings on metals [4].

Nanoparticles are commonly defined as particles with the size of at least one dimension ranging from 1 to $100 \mathrm{~nm}$ which serve as a bridge between bulk materials and atoms/molecules. In recent decades, nanoparticles have been applied in

*Department of Chemistry /College of Science for Women /University of Baghdad.

**Department of Chemistry /College of Science /University of Baghdad. 
many areas because of their unique size-dependent physicochemical, electromagnetic, optical, and chemical catalytic properties. Nanotechnology is referred to as the emerging technology involving fabrication or application of nanosized structures or materials[5]

The aim of the work is applying nanomaterials (zinc oxide or alumina) as a coating layer for protection carbon steel and stainless steel from corrosion in saline water.

\section{Materials and Methods:}

\section{Solution preparation}

The solution was prepared by adding $35 \mathrm{~g}$ of $\mathrm{NaCl}$ to $1 \mathrm{~L}$ of distilled water .

\section{Sample preparation}

The investigated materials were (Carbon Steel and Stainless Steel). The materials were fabricated in circular samples with dimensions of $2.5 \mathrm{~cm}$ in diameter, the specimen of Carbon Steel was further cleaned just, prior to immersion in $\mathrm{HCl}$ solution (10$15) \%$ for (10) $\mathrm{min}$, where the specimens of Stainless Steel were degreased with acetone and washed distilled water, and finally with ethanol thereafter, the specimens were put inside desiccators until doing the tests.

\section{Preparation of Corrosion Cell}

The electrochemical system consists of computerized advanced potentiostate, with standard three electrodes double wall Pyrex glass of (1L) capacity corrosion cell. Chiller device was used to control the temperature of the measurement at (2050) ${ }^{\circ} \mathrm{C}$. Figure (1) shows the corrosion cell and the three electrodes.

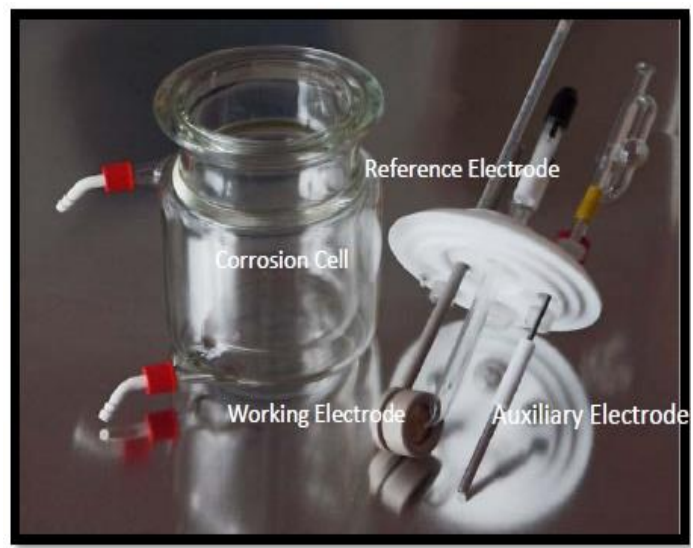

Fig. (1) Set up the corrosion cell and three electrode

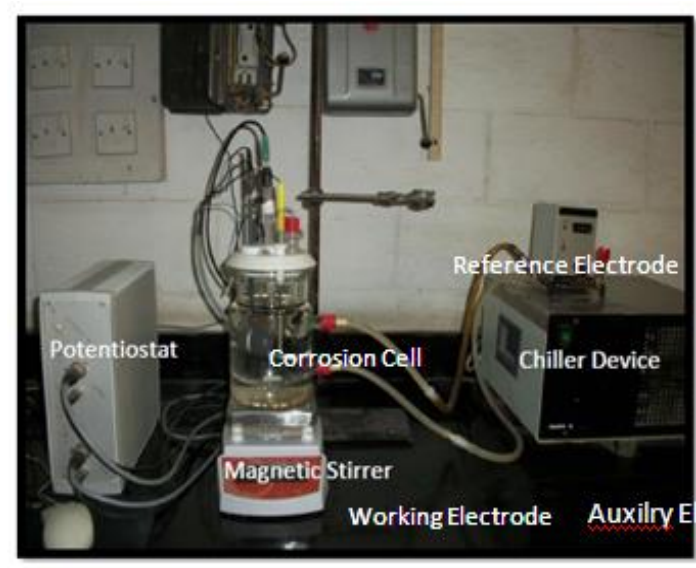

Fig. (2) Complete system set up for polarization measurements

\section{Preparation of Emulsion Solution}

The solution was prepared by adding deionized water as a solvent to ( $1 \mathrm{~g}$ of $\mathrm{Al}_{2} \mathrm{O}_{3}$ ) and (1 $\mathrm{g}$ of $\left.\mathrm{ZnO}\right)$ powders to homogenize the solutions, magnetic mixture was used for $30 \mathrm{~min}$. Figure (3) shows the emulsion solution. The solutions were applied for coating the specimen by using air atomizer coating technique, the next step adding ( $1 \mathrm{~g})$ sodium silicate to the previous solutions in order to get a better adherence between the coating layer and the metal surface. 


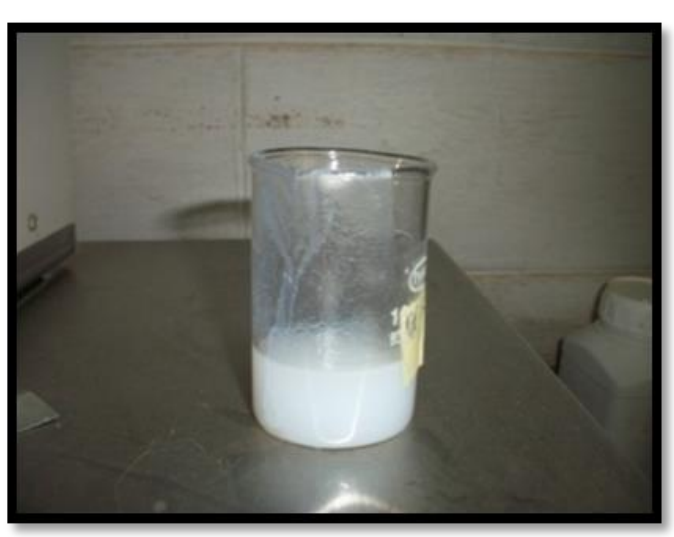

Fig. (3) The emulsion solution.

\section{Air Atomizer Coating Technique:}

Air atomizer was used as spraying technique which composed of the following components:

1. Electrical heater was used to heat the specimen to about 100-150 C.

2. Temperature measurement device as thermocouple was used to measure the specimen temperature.

3. Air compressor was used to compress air into the atomizer.

4. Air atomizer unit, which contains solution container, valve used to control the solution flow and a nozel with small orifice used to spray the solution using the compressed air. The nozel was directed onto the specimen surface.

The nozel of the air atomizer unit must be placed about $(10 \mathrm{~cm})$ above the specimen which heating of the specimens will help to improve the adhesion between the coating layer and the metal surface. Figure (4) shows the air atomizer set up system, and figure (5) shows the unmounted specimens coated by air atomizer technique.

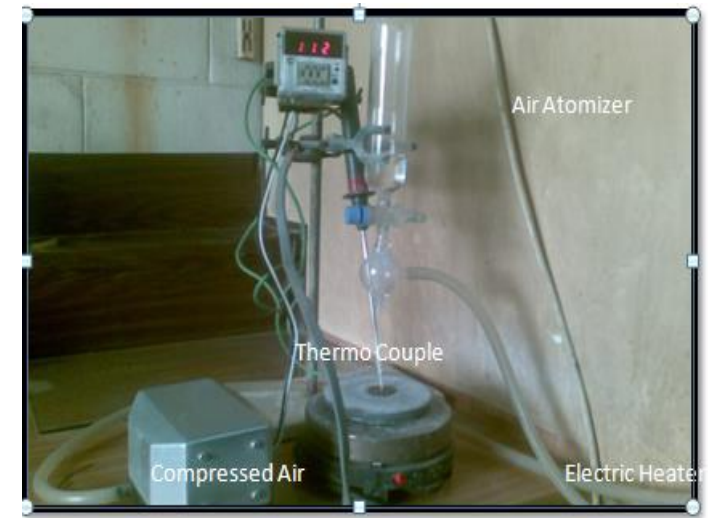

Fig. (4) The air atomizer set up system.

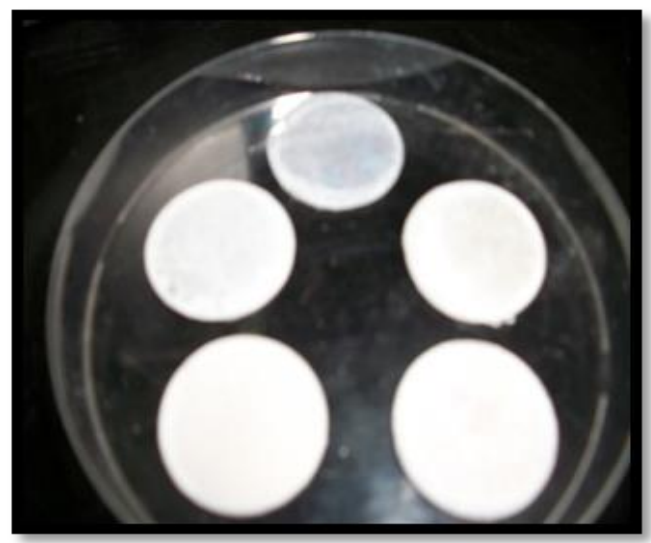

Fig. (5) The unmounted specimens coated by using air atomizer technique

\section{Results and Discussions:}

The surface morphologies and compositions of coating $\mathrm{Al}_{2} \mathrm{O}_{3}$ using atomic force microscope (AFM) applied on stainless steel in sea water $(3.5 \% \mathrm{NaCl})$ at different temperatures. Comparison of coating and uncoated specimens by Tafel extrapolation method using advanced potentiostat with three electrodes standard cell.

\section{The Surface Morphology Analysis by AFM.}

The AFM images of the $\mathrm{AL}_{2} \mathrm{O}_{3}$ sodium silicate $\left(\mathrm{Na}_{2} \mathrm{SiO}_{3}\right)$ layers which applied only with the procedure showed a degree of agglomeration of the nanoparticles due to adhesiveness of sodium silicate and the produced layer are higher density greater adhesive with larger particles ,figure 
(6) shows atomic force microscope images of $\mathrm{Al}_{2} \mathrm{O}_{3}-\mathrm{NaSiO}_{2}$ nanoparticles applied on stainless steel, the particle size distribution shows in figure (7)and the average particles size around 53.15 nm.

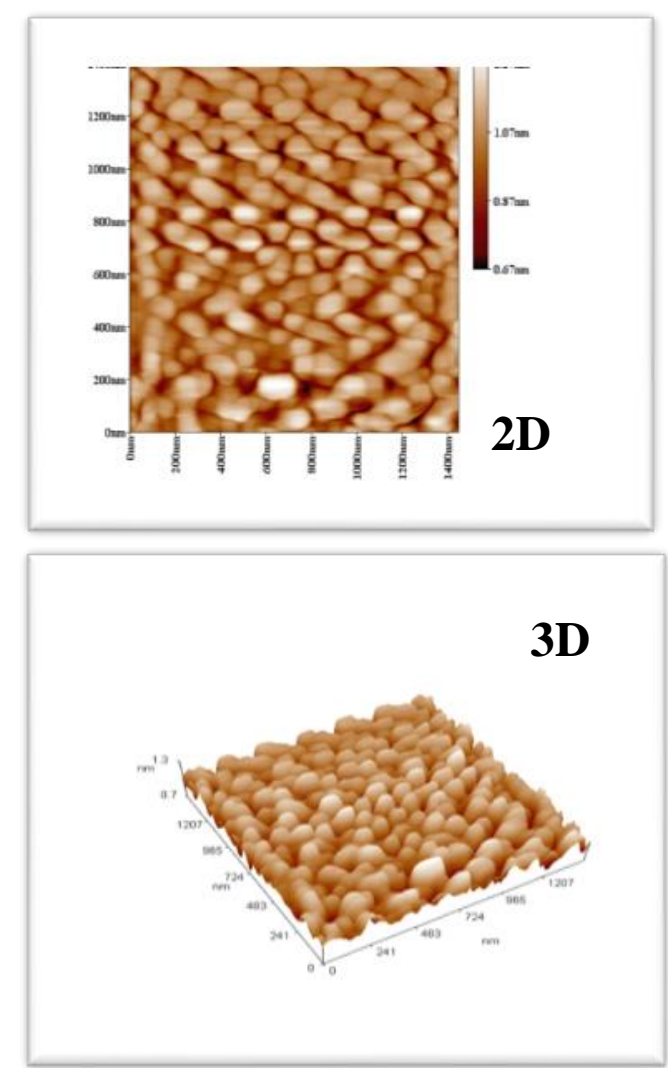

Fig.(6) 2D and 3D views of AFM image of $\mathrm{AL}_{2} \mathrm{O}_{3}-\mathrm{NaSiO}_{2}$ nanoparticles applied on stainless steel.

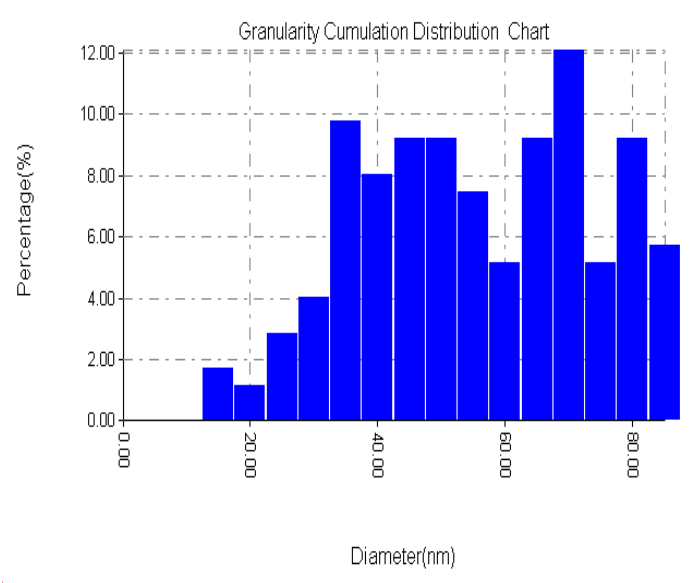

Fig.(7) view of granularity normal distribution chart of $\mathrm{Al}_{2} \mathrm{O}_{3}-\mathrm{NaSiO}_{2}$ nanoparticles .

\section{Corrosion Protection Study:}

The corrosion protection properties of all applied nanostructured layers on two types of specimens; Carbon Steel, Stainless Steel, in artificial sea water $(3.5 \% \mathrm{NaCl})$ at different temperatures. They were established using electrochemical method via Tafel polarization curves.The layers of; $\mathrm{AL}_{2} \mathrm{O}_{3}, \mathrm{ZnO}$ mixture with sodium silicate were applied by; EPD and air atomizer. The measurements of each metal corrosion potentials $\left(\mathrm{E}_{\text {corr }}\right)$, corrosion current densities ( $\left.\mathrm{I}_{\text {corr }}\right)$, corrosion rates $(\mathrm{CR})$, and penetrations rates (PR).

Protection efficiencies (PE) of all types of coating estimated by comparison with the measurements of the uncoated surface of each type of specimens using equation

$$
\mathrm{PE}=\frac{\left(\mathrm{I}_{\text {cor }}\right)_{\text {un couted }}-\left(\mathrm{I}_{\text {cor }}\right)_{\text {coated }}}{\left(\mathrm{I}_{\text {cor }}\right)_{\mathrm{un} \text { couted }}}
$$

\subsection{Corrosion Protection of Carbon Steel Specimens :}

Protection capabilities of the nanomaterial coatings on carbon steel specimens in the brine environment $(3.5 \% \mathrm{NaCl})$ correlated to the type of coating applied. The best protection efficiency (PE) was obtained using air atomizer for alumina (63.8-67\%) on the carbon steel while the protection efficiency for $\mathrm{ZnO}$ was (58-68\%). Table (1) shows all measurements and calculations conducted from Tafel curves.

Table (1) The values of $\mathbf{E}_{\text {corr. }}, \mathbf{I}_{\text {corr }}$, W.l.and pent.l. of the uncoated carbon steel at different temperature by using air atomizer method.

\begin{tabular}{|c|c|c|c|c|}
\hline $\begin{array}{c}\mathrm{T} \\
(\mathrm{K})\end{array}$ & $\begin{array}{c}\mathrm{E}_{\text {corr }} \\
(\mathrm{mv})\end{array}$ & $\mathrm{I}_{\text {corr }}\left(\mu \mathrm{A} / \mathrm{cm}^{2}{ }^{2}\right)$ & $\begin{array}{c}\text { W.L. } \\
\left(\mathrm{g} / \mathrm{m}^{2} \mathrm{~d}\right)\end{array}$ & $\begin{array}{c}\text { Pent } \\
(\mathrm{mm} / \mathrm{a})\end{array}$ \\
\hline 293 & -367 & 93.91 & 23.5 & 1.09 \\
\hline 303 & $499.1-$ & 103.36 & 25.8 & 1.2 \\
\hline 313 & -600.3 & 110.32 & 27.6 & 1.28 \\
\hline 323 & -650 & 139.88 & 35 & 1.62 \\
\hline
\end{tabular}




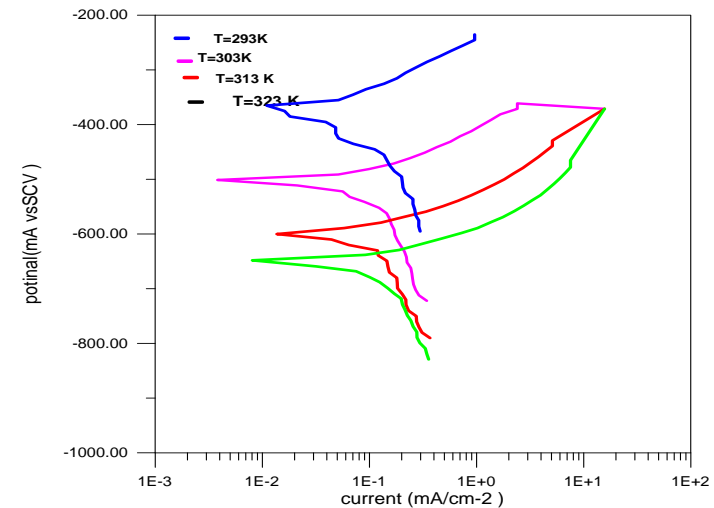

Fig.(8) shows the polarization curves of uncoated carbon steel at different temperatures.

Table (2) The values of $E_{\text {corr., }} \mathbf{I}_{\text {corr }}$, p\%, W.L. and pent. of the carbon steel coated with $\mathrm{Al}_{2} \mathrm{O}_{3}$ at different temperature by using air atomizer method.

\begin{tabular}{|c|c|c|c|c|c|}
\hline $\begin{array}{c}\mathrm{T} \\
(\mathrm{K})\end{array}$ & $\begin{array}{c}\mathrm{E}_{\text {corr }} \\
(\mathrm{mv})\end{array}$ & $\begin{array}{c}\mathrm{I}_{\text {corr }}(\mu \\
\left.\mathrm{Acm}^{-2}\right)\end{array}$ & $\mathrm{P} \%$ & $\begin{array}{c}\text { W.L. } \\
\left(\mathrm{g} / \mathrm{m}^{2} \mathrm{~d}\right)\end{array}$ & $\begin{array}{c}\text { Pent } \\
(\mathrm{mm} / \mathrm{a})\end{array}$ \\
\hline 293 & -474.2 & 33.72 & 63.8 & 8.43 & 0.391 \\
\hline 303 & -582.9 & 33.72 & 67 & 8.15 & 0.448 \\
\hline 313 & -548.2 & 38.30 & 66 & 9.66 & 0.409 \\
\hline 323 & -590.8 & 48.01 & 65 & 12 & 0.557 \\
\hline
\end{tabular}

The protection efficiencies of carbon steel coating with $\mathrm{Al}_{2} \mathrm{O}_{3}$ in $3.5 \%$ $\mathrm{NaCl}$ ) increasing at $303 \mathrm{~K}$.

Table (3) The values of $\mathbf{E}_{\text {corr. }}, \mathbf{I}_{\text {corr }}$, p\%, W.l.and pent.l. of the carbon steel coated with $\mathrm{ZnO}-\mathrm{NaSiO}_{2}$ with different temperature by using air atomizer method.

\begin{tabular}{|c|c|c|c|c|c|}
\hline $\begin{array}{c}\mathrm{T} \\
(\mathrm{K})\end{array}$ & $\begin{array}{c}\mathrm{E}_{\text {corr }} \\
(\mathrm{mv})\end{array}$ & $\begin{array}{c}\mathrm{I}_{\text {corr }}(\mu \\
\left.\mathrm{Acm}^{-2}\right)\end{array}$ & $\mathrm{P} \%$ & $\begin{array}{c}\text { W.L. } \\
\left(\mathrm{g} / \mathrm{m}^{2} \mathrm{~d}\right)\end{array}$ & $\begin{array}{c}\text { Pent } \\
(\mathrm{mm} / \mathrm{a})\end{array}$ \\
\hline 293 & -377.7 & 38.9 & 58.3 & 9.76 & 0.434 \\
\hline 303 & -533.6 & 39.6 & 61.3 & 9.94 & 0.442 \\
\hline 313 & -563.9 & 41.7 & 63.4 & 10.4 & 0.465 \\
\hline 323 & -626.7 & 44.0 & 67.8 & 11.0 & 0.492 \\
\hline
\end{tabular}

The protection efficiencies of carbon steel coating with $\mathrm{ZnO}-\mathrm{NaSiO}_{2}$ in $(3.5 \% \mathrm{NaCl})$ increasing at $323 \mathrm{~K}$.

\subsection{Corrosion Protection of stainless Steel Specimens}

Protection capabilities of the nanomaterial coatings on stainless steel specimens in the brine environment $(3.5 \% \mathrm{NaCl})$ correlated to the type of coating applied. The best protection efficiency (PE) was obtained using air atomizer method for alumina (70.3$83 \%$ ) on the stainless steel while the protection efficiency for $\mathrm{ZnO}$ was (63-79\%).

Table (4) The values of $\mathbf{E}_{\text {corr. }}, \mathbf{I}_{\text {corr }}$, W.L. and pent. of the stainless steel uncoated with different temperature by using air atomizer method

\begin{tabular}{|c|c|c|c|c|}
\hline $\begin{array}{c}\mathrm{T} \\
(\mathrm{K})\end{array}$ & $\begin{array}{c}\mathrm{E}_{\text {corr }} \\
(\mathrm{mv})\end{array}$ & $\begin{array}{c}\mathrm{I}_{\text {corr }}(\mu \\
\left.\text { Acm }^{2}\right)\end{array}$ & $\begin{array}{c}\text { W.L. } \\
\left(\mathrm{g} / \mathrm{m}^{2} \mathrm{~d}\right)\end{array}$ & $\begin{array}{c}\text { Pent } \\
(\mathrm{mm} / \mathrm{a})\end{array}$ \\
\hline 293 & -200 & 13.6 & 3.41 & 0.152 \\
\hline 303 & -219.6 & 14.7 & 3.68 & 0.164 \\
\hline 313 & -232.1 & 15.63 & 3.92 & 0.174 \\
\hline 323 & -248 & 16.2 & 4.08 & 0.181 \\
\hline
\end{tabular}

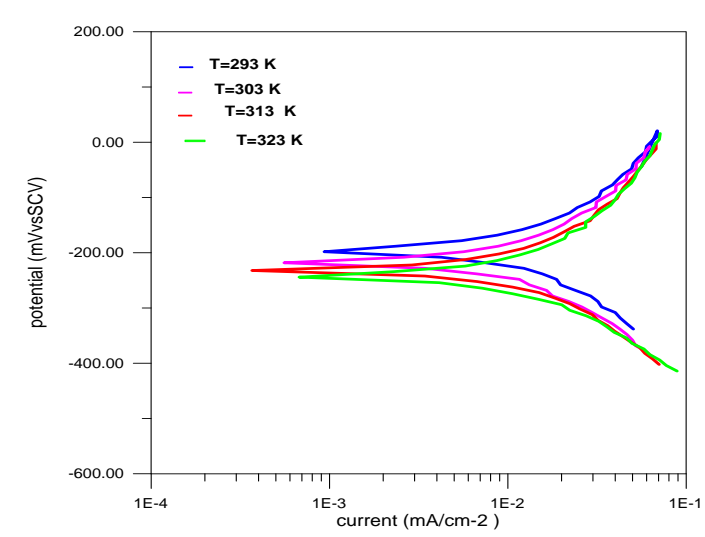

Fig. (9) shows the polarization curves of stainless steel Uncoated with different temperature.

Table (5) The values of $\mathbf{E}_{\text {corr. }}, \mathbf{I}_{\text {corr }}$, W.L. and pent. of the stainless steel coated with $\mathrm{Al}_{2} \mathrm{O}_{3}$ with different temperature by using air atomizer method.

\begin{tabular}{|c|c|c|c|c|c|}
\hline $\begin{array}{c}\mathrm{T} \\
(\mathrm{K})\end{array}$ & $\begin{array}{c}\mathrm{E}_{\text {corr }} \\
(\mathrm{mv})\end{array}$ & $\begin{array}{c}\mathrm{I}_{\text {corr }} \\
\left(\mu \mathrm{Acm}^{2}\right)\end{array}$ & $\mathrm{P} \%$ & $\begin{array}{c}\text { W.L. } \\
\left(\mathrm{g} / \mathrm{m}^{2}\right. \\
\mathrm{d})\end{array}$ & $\begin{array}{c}\text { Pent } \\
(\mathrm{mm} / \mathrm{a})\end{array}$ \\
\hline 293 & 52.8 & 2.2 & 83 & 0.543 & 0.0242 \\
\hline 303 & 58.8 & 2.3 & 83.4 & 0.689 & 0.0614 \\
\hline 313 & 23.5 & 3.08 & 80.3 & 0.767 & 0.0341 \\
\hline 323 & 39.1 & 4.8 & 70.3 & 0.124 & 0.0551 \\
\hline
\end{tabular}




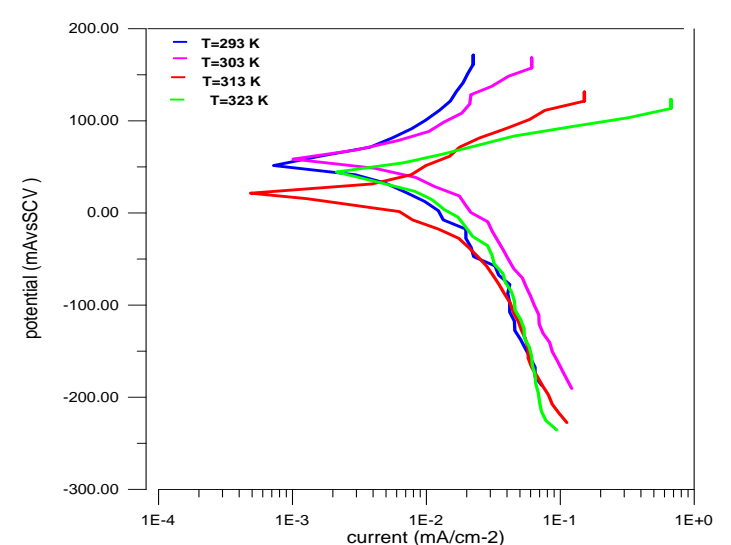

Fig. (10) shows the polarization curves of stainless steel coated with $\mathrm{Al}_{2} \mathrm{O}_{3}$ at different temperatures.

The protection efficiencies of stainless steel coating with $\mathrm{Al}_{2} \mathrm{O}_{3}$ in $(3.5 \% \mathrm{NaCl})$ increasing at $303 \mathrm{~K}$.

Table (6) The values of $\mathbf{E}_{\text {corr. }}, \mathbf{I}_{\text {corr }}$, W.l. and pent.. of the stainless steel coated with $\mathrm{ZnO}$ at different temperature.

\begin{tabular}{|c|c|c|c|c|c|}
\hline $\begin{array}{c}\mathrm{T} \\
(\mathrm{K})\end{array}$ & $\begin{array}{c}\mathrm{E}_{\text {corr }} \\
(\mathrm{mv})\end{array}$ & $\begin{array}{c}\mathrm{I}_{\text {corr }} \\
\left(\mu \mathrm{A} . \mathrm{cm}^{-2}\right)\end{array}$ & $\mathrm{P} \%$ & $\begin{array}{c}\mathrm{W} . \mathrm{L} . \\
\left(\mathrm{g} / \mathrm{m}^{2} \mathrm{~d}\right)\end{array}$ & $\begin{array}{c}\text { Pent } \\
(\mathrm{mm} / \mathrm{a})\end{array}$ \\
\hline 293 & $\begin{array}{c}- \\
149.6\end{array}$ & 2.80 & 79 & 0.691 & 0.0308 \\
\hline 303 & $\begin{array}{c}- \\
157.7\end{array}$ & 4.95 & 65 & 0.124 & 0.0552 \\
\hline 313 & $\begin{array}{c}- \\
165.5\end{array}$ & 5.5 & 64 & 1.35 & 0.0600 \\
\hline 323 & $\begin{array}{c}- \\
162.2\end{array}$ & 6.0 & 63 & 1.38 & 0.0615 \\
\hline
\end{tabular}

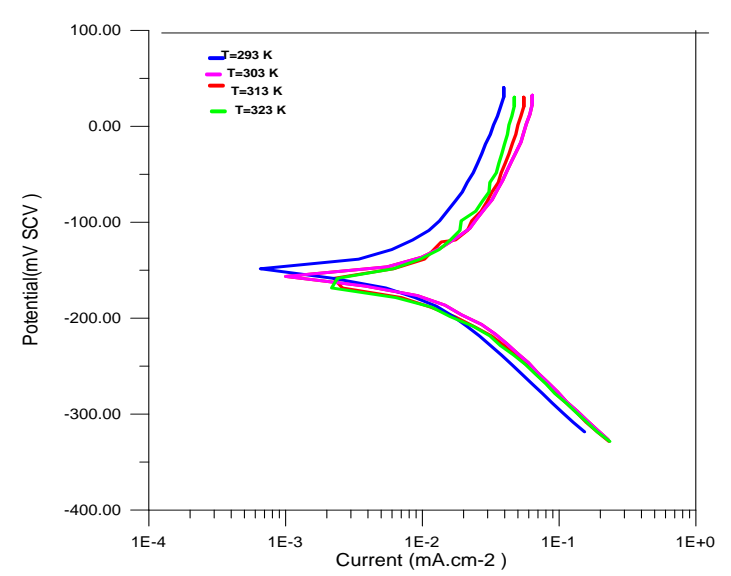

Fig. (11) shows the polarization curves of stainless steel coated with $\mathrm{ZnO}$ at different temperatures.

The protection efficiencies of stainless steel coating with $\mathrm{ZnO}$ in $(3.5 \% \mathrm{NaCl})$ increasing at $293 \mathrm{~K}$.

\section{Conclusions:}

AFM inspections revealed useful data on particle size and shape, $\mathrm{AL}_{2} \mathrm{O}_{3}$ particles seem to keep their origin particles size $(\sim 50 \mathrm{~nm})$ with well packed homogenized layer .The same topographic results appeared with EPD , they also showed particles sizes nearly around the origin size $(\sim 50 \mathrm{~nm})$. Mixture of $\mathrm{ZnO}_{2}$ and $\mathrm{Na}_{2} \mathrm{SiO}_{3}$ produces a highly adhered layer with particle size of $30 \mathrm{~nm}$.

It is clear the coating $\mathrm{ZnO}$ nanopartical applied has enhanced corrosion protection then coating $\mathrm{Al}_{2} \mathrm{O}_{3}$ layers. Comparison between the protection efficiencies at different temperature between carbon steel and stainless steel with coating $\mathrm{ZnO}-$ $\mathrm{NaSiO}_{2}$ and $\mathrm{Al}_{2} \mathrm{O}_{3}-\mathrm{NaSiO}_{2}$ in $(3.5 \%$ $\mathrm{NaCl}$ ) can be shown in table(7).

Table(7) Comparison between the protection efficiencies at different temperature between carbon steel and stainless steel with coating $\mathrm{ZnO}-\mathrm{NaSiO}_{2}, \mathrm{ZnO}$ and $\mathrm{Al}_{2} \mathrm{O}_{3}$ in (3.5\% NaCl).

\begin{tabular}{|c|c|c|c|c|}
\hline \multirow{2}{*}{$\mathrm{T}(\mathrm{K})$} & \multicolumn{2}{|c|}{$\mathrm{P} \%$ Carbon steel } & \multicolumn{2}{c|}{$\mathrm{P} \%$ stainless steel } \\
\cline { 2 - 5 } & $\mathrm{Al}_{2} \mathrm{O}_{3}$ & ${\mathrm{ZnO}-\mathrm{NaSiO}_{2}}$ & $\mathrm{Al}_{2} \mathrm{O}_{3}$ & $\mathrm{ZnO}$ \\
\hline 293 & 63.8 & 58.3 & 83 & 79 \\
\hline 303 & 67.0 & 61.3 & 83.4 & 65 \\
\hline 313 & 66.4 & 63.4 & 80.3 & 64 \\
\hline 323 & 65.0 & 67.8 & 70.3 & 64 \\
\hline
\end{tabular}

\section{References:}

1. Zheludkevich. M. L, Shchukin .D. G, Yasakau. K. A, Möhwald. H, and Ferreira .M. G. S, 2007. Anticorrosion Coatings with SelfHealing Effect Based on Nanocontainers Impregnated with Corrosion Inhibitor, Chem. Mater. 19, 402-411.

2. Bentiss .F, Lebrini. M, and Lagrenée .M, 2005. Thermodynamic characterization of metal dissolution and inhibitor adsorption processes in mild steel/ 
2,5-bis(n-thienyl)-1,3,4thiadiazoles/ hydrochloric acid system, Corr. Sci. 47, 2915-2931.

3. Haruna. T, Morikawa .Y, Fujimoto. S, and Shibata .T, 2003. Electrochemical noise analysis for estimation of corrosion rate of carbon steel in bicarbonate solution, Corr. Sci. 45, 20932104.

4. Bektash . A. A, 2010. A Study in Protection of Corrosion by Using
Nanoparticles $\left(\mathrm{TiO}_{2}, \quad \mathrm{SiO}_{2}\right)$ for Some Metals and Alloys, M.Sc thesis, Department of Chemistry , College of Science for Women University of Baghdad.

5. Jia you. 2010. metallic nanotoxicity to bacteria bacteriophage, M.Sc thesis, the Faculty of the Graduate School ,University of Missouri.

\section{دراسة حماية التاكل للكاربون ستيل وسبيكة الستتلس ستيل 316 بواسطه التغطية بمواد نانوية}

عبد الكرييم محد عليش*:

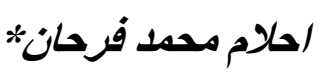

رشا عبد جاسمث*

*قسم الكيمياء /كلية العلوم للبنات /جامعة بغداد.

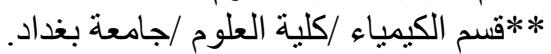

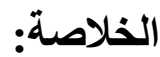

دراسة حماية التأكل لسبيكتي حليد الصلب 316 والفولاذ الكاربوني المنطاة بدقائق نانوية

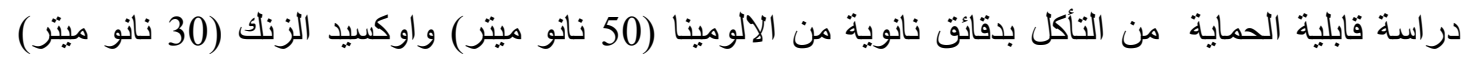
لسبيكتي حديد الصلب 316 و الفو لاذ الكاربوني بماء البحر (50,40,30,20)

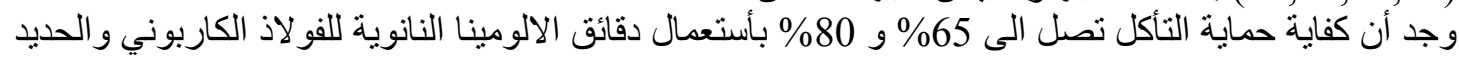

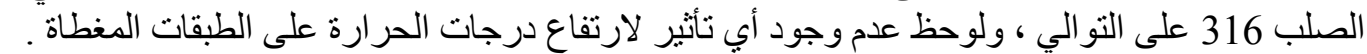

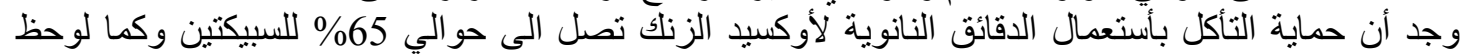

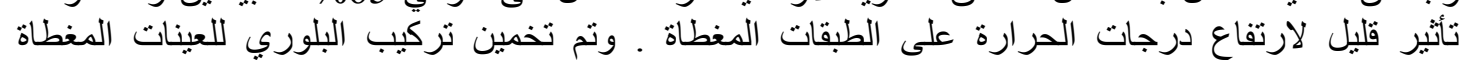
بأستخدام مجهر القوة الذرية. 